\title{
Cooperation or confrontation? \\ Exploring stakeholder relationships in rural tourism land expropriation
}

\begin{abstract}
The current study explored the triadic relationship between the government, local residents and developers as stakeholders in rural tourism land expropriation. Unstructured interviews and non-participant observation were conducted to obtain relevant data. Social action theory was applied to delineate the complex interaction and relationships between the various stakeholders. Growth machine theory was also used to reveal the internal mechanisms of these relationships. The results showed that in land expropriation for rural tourism development in the case setting, stakeholders' relationships were not merely cooperative or antagonistic; rather, their interests were interwoven and showed a process-based evolution with the progress of land expropriation. Finally, the local government (political elite) and the developer (economic elite) formed a growth coalition and jointly led the process of land expropriation. However, local residents failed to form an anti-growth coalition, which indicates the potential vulnerability of tourism coalition formation. These insights have implications for developing sustainable tourism, including government involvement and resident participation, particularly in the context of developing countries.
\end{abstract}

Keywords: Tourism stakeholders; Social action; Growth machine; Land expropriation; Rural tourism

\section{Introduction}

Sustainable tourism depends on harmonious cooperation between stakeholders (Qian et al., 2017). Collaboration requires adequate power to convene stakeholders (Purdy, 2012). This is particularly true of rural tourism development. Rural tourism has been regarded as an essential developmental strategy in many countries (Ayhan et al., 2020), especially in developing countries, where tourism is regarded as an important means of poverty alleviation and the key to local economic development (Ying \& Zhou, 2007). China is a good example (Su, 2011). By the end of 2018, China's Ministry of Agriculture and Rural Affairs had established 388 national demonstration sites for rural tourism, receiving 3 billion tourist visits and generating RMB800 billion in revenue (Ministry of Agriculture and Rural Affairs, 2019).

Rural tourism is booming, and the demand for tourism land is increasing. Land expropriation, which involves multiple stakeholders in complex relationships, is more common in China than land renting, which is characterised by simple bilateral stakeholder relationships. Local governments play a leading role in the process (Wang \& Wall, 2007). Due to its multiple subjects and complicated procedures, land expropriation creates very tense relationships between stakeholders. Therefore, land expropriation was chosen as the research context for the current investigation. Rural land expropriation in China is distinct from that in the West due to its unique top-down administrative system and socialist dual-track land ownership system. These two unique institutional features (Cai, 2016) place the government in the leading position (Wang \& Wall, 2007) and residents in the weak position ( $\mathrm{Li}$ et al., 2016) in land expropriation. However, compared with land expropriation for other purposes, such as dams, public works and investment projects, land expropriation for tourism development is more likely to be welcomed by residents (Hernandez et al., 1996). Residents believe that tourism development will bring them more job opportunities, and they seek to participate to improve their quality of life (Cai, 2016). These expectations increase the complexity of stakeholder relationships and aggravate conflict between stakeholders in the 
land expropriation process (Sargeson, 2016; Wang \& Yotsumoto, 2019). Therefore, strengthening cooperation between different stakeholders and identifying common interests are key to attaining sustainable tourism development (Sautter \& Leisen, 1999).

However, little attention has been paid to the roles of different stakeholders in addressing sustainable tourism development (Wray, 2009), or to the interaction between stakeholders and the logic underlying their actions (Wearing et al., 2010; Lee \& Jan, 2019). Given the paucity of research in this area and the importance of land expropriation to sustainable tourism development, this study aims to identify the different roles of stakeholders and determine how to promote cooperation between stakeholders in the land appropriation process of rural tourism (Byrd, 2007; Hardy \& Beeton, 2001). Based on this, three key questions are asked. In the land expropriation stage of rural tourism development, do all key stakeholders really participate? How do stakeholders interact, and what relationships do they form? What logic is their actions guided by, and what is its internal mechanism? The study's findings enrich research on tourism stakeholders and provide a point of reference and guidance for sustainable tourism development in developing countries.

\section{Literature Review}

\subsection{Stakeholder cooperation in tourism development}

'Stakeholders' refers to any group or individual that can affect or be affected by the goals of the organisation (Freeman, 1984: p. 46). Weaver and Oppermann (2000) defined tourism stakeholders as comprising mainly tourists, tourism businesses, the origin government, the host government, host communities, non-governmental organisations and universities. A map of tourism stakeholders was drawn by Weaver and Oppermann (2000). There are different tourism stakeholders in different tourism scenarios. However, there is no doubt about the importance of stakeholders to current and future tourism development (Jamal \& Getz, 1999).

Studies have focused on analysing and categorising stakeholders (Byrd, 2007; Hardy \& Beeton, 2001). A growing number of researchers have argued that stakeholder cooperation/collaboration is fundamental to sustainable tourism planning and destination development (Jamal \& Stronza, 2009; Qian et al., 2017; Sautter \& Leisen, 1999; Stoddarta et al., 2019; Wondirad et al., 2020). Waligo et al. (2013) discussed how relevant stakeholders participate in sustainable tourism and formed a multi-stakeholder involvement management framework. However, the nature of cooperation and why it does not occur between certain stakeholders have not been fully explored (Wearing et al., 2010). This study thus explores the specific processes of interaction and the complicated relationships between stakeholders during land expropriation for rural tourism development.

\subsection{Factors influencing stakeholder cooperation}

Scholars have emphasised the importance of stakeholder participation to sustainable tourism development and called on stakeholders to cooperate on tourism (Waligo et al., 2013). However, stakeholders are so diverse and heterogeneous that it is extremely difficult and complicated for them to participate in this process (Jamal \& Getz, 1999; Waligo et al., 2013). Different stakeholders hold different views and positions (Markwick, 2000). Studies have shown that the degree of stakeholders' participation varies according to their interests and level of empowerment (Panyik et al., 2011). Therefore, power and interest are important factors affecting the cooperation of stakeholders.

Stakeholders in cooperation can be identified and distinguished based on their interests (Donaldson \& Preston, 1995: 67). Different subjects have different interests (Donaldson \& Preston, 1995). For example, in the process of tourism development, local governments and 
entrepreneurs may pay particular attention to economic benefits (Dredge, 2010). For residents, economic benefits are most pertinent in the involvement stage (Kim et al., 2013). Local residents want to improve their quality of life (Brunt \& Courtney, 1999). Conflicts often arise when different parties have incompatible interests and seek to achieve different outcomes (Wang \& Yotsumoto, 2019).

Power is also an important factor affecting stakeholder interaction (Jamal \& Getz, 1999), and shapes the overall distribution of benefits (Ying \& Zhou, 2007). In reality, there is always an imbalance of power between stakeholders (Bramwell \& Sharman, 1999; Jamal \& Getz, 1999). Power often rests with an established local elite, which supersedes the salient majority (local residents) (Hall, 1999; Tosun, 2000). This imbalance of power leads to conflicts among stakeholders, especially in the tourism planning stage. As noted by Ploger (2001), planning is a form of discursive power. It can also be a process, during which conflicts emerge over power relationships that reflect the entrenchment of strong economic or social interests (Hanna, 2005).

To date, although research has explored cooperation between stakeholders, it has ignored the interaction and relationships between stakeholders in tourism development (Lee \& Jan, 2019). Yet clarifying the specific logic of stakeholders' interaction and action and seeking common interests among them are vital to promote cooperation among stakeholders and guide the sustainable development of rural tourism. This study focuses on identifying stakeholders' different roles and finding ways to promote cooperation between them in the process of land appropriation for rural tourism.

\subsection{Stakeholders in land expropriation for rural tourism in China}

The main stakeholders involved in land expropriation for rural tourism in China are local governments, tourism developers and residents (Ma et al., 2020). Different stakeholders play different roles in rural tourism land expropriation.

Local governments play the leading role in rural tourism development (Wang \& Wall, 2007). There are several reasons for this. The first is China's characteristic socialist land system. Second, China has a dual-track land system. According to China's Land Administration Law, states own all urban land and village collectives own all rural land, subject to restrictions on land use and transfer. To achieve tourism development through land expropriation, the government needs to expropriate land from residents and then sell the land use rights to the developers (Guo, 2001). In addition, China's top-down administrative system requires the central government to make decisions and local governments at all levels to implement these decisions (Qin et al., 2011). This strengthens the local government's dominant position.

Local governments are the political subject and hold the administrative power in local tourism development. However, in the process of rural tourism development in China, local governments lack the financial support required to develop and build tourist destinations ( $\mathrm{Li}$ et al., 2016; Zhou et al., 2017), including land expropriation compensation payments for residents and follow-up project construction funds. These are provided by tourism developers, which have a strong economic foundation. Tourism developers and their external capital provide important economic support for tourism development in backward rural areas ( $\mathrm{Li}$ et al., 2016; Ying \& Zhou, 2007; Zhou et al., 2017). This is significantly different from the responsibility relationship between the private sector and the government in Western society. In China, tourism developers and the government have interwoven interests (Ying \& Zhou, 2007).

Residents are the main agents in rural tourism, and their willingness to promote and attitude towards promoting tourism affect the smooth development of tourism projects and the stable development of rural society (Ma et al., 2020). Residents' participation in tourism 
is an important element of sustainable tourism development (Tosun, 2000). However, research has shown that residents in developing countries are in a weak position in the decision-making stage of tourism development ( $\mathrm{Li}$ et al., 2016). The rights of residents are seriously limited in the power play of stakeholders in tourism development (Wang \& Yotsumoto, 2019; Ying \& Zhou, 2007). Compensation for land under China's planned economic system is much lower than the value of land in a market economy (Guo \& Gao, 2014). Land is the most important asset of the majority of rural residents, because it functions as both a source of income and a mechanism of social insurance (Cai, 2016). Power distribution plays an important and even a decisive role in community participation, and tourism development in rural China is a power play for benefits between the government (at various levels), tourism developers and local communities (Wang \& Yotsumoto, 2019).

Land expropriation, which is central to the government's strategies for development and capital accumulation, has frequently encountered fierce opposition from residents and led to extreme social conflict (Sargeson, 2016; Wang \& Yotsumoto, 2019). Therefore, deconstructing the logic of the interaction and relationships between and actions taken by different agents in the process of land expropriation for rural tourism development can help guide the sustainable development of rural tourism and social harmony in developing countries like China.

\section{Theoretical framework}

\subsection{The theory of social action}

Max Weber's social action theory is adopted to understand the process of interaction of individual stakeholders in land expropriation for rural tourism development. Social action has two key features. First, the action has a purpose, and the actor endows the action with a certain significance (Weber, 1978). Individuals are seen as goal-directed, guided by both their own interests and constraints imposed by the social environment (Coleman, 1986). Second, their actions are oriented by the behaviour of others, through connections between individuals' behaviour in the social sphere (Banton, 2007; Weber, 1949). Following Weber's logical interpretation of social action, this paper uses 'actor-goal-action' analysis to deconstruct the processes of interaction and forms of relationships between stakeholders in land expropriation for tourism development. In land expropriation for tourism development, the social actions of the actors are reflected through typical events. Therefore, the final framework for analysis is 'actor-goal-action-typical events'. Social action theory is applied to delineate the complex interaction of and obtain detailed information on various stakeholders to answer the following research questions. In the land expropriation stage of rural tourism development, do all key stakeholders really participate? How do stakeholders interact, and what forms do their relationships take?

\subsection{Growth machine theory}

Molotch (1976) first proposed the concept of a 'growth machine'. He argued that cities can be conceived as growth machines, and that the future use of and competition for land represent the political and economic essence of any locality. Follow-up studies further developed the growth machine thesis (Molotch \& Logan, 1984; Sanders \& Stone, 1987). In a liberal democratic society, cities have a unitary interest in growth and economic development. The fundamental challenge facing local governments is the conflict between public power and private resource ownership. Thus, coalitions often form between local governments, which represent the elected public authority, and business groups, which control major development resources, in urban governance (Stone, 1993). However, conditions affecting the quality of life in a community are a consequence of the social, economic, and political power 
wielded by the growth machine. Local nested communities within the larger community tend to develop in reaction to the decisions made by the growth machine (Molotch, 1976; Zhang, 2002).

For tourism researchers, growth machine theory offers a theoretical context for explaining local economic growth and development through political coalitions and land use allocation (Harrill et al., 2011). Only a handful of tourism researchers to date have used growth machine theory (Green et al., 1996). Canan and Hennessy's (1989) application of growth machine theory to the Hawaiian island of Moloka'i revealed an economic transition from agriculture to tourism, followed by land use conflict over resort development and finally the erosion of local culture. Madrigal (1995) noted that an internal marketing strategy should be conducted within a socially conscious framework that is designed to serve the needs of the community, not members of the growth machine. In a study of Hilton Head in South Carolina, USA, Martin et al. (1999) found a relatively wealthy anti-growth coalition. Harrill et al. (2011) used growth machine theory as a context for identifying Macao residents' attitudes towards gaming and tourism development. The case of Wudaoliang shows interesting points of congruence with Molotch's thesis: elites competed and sometimes aligned in land expropriation conflicts over rapid tourism development, with profound consequences for the local community's life and interests. Growth machine theory is used as the main framework for analysis to reveal the logic and internal mechanisms of the actions of different stakeholders. The overall analysis of the formation of the Wudaoliang tourism growth machine is based on detailed process information on the interaction between subjects obtained by social action theory. With the guidance of both social action theory and growth machine theory, the following research question is addressed. What are the logic and internal mechanisms of stakeholders' actions and interaction?

\section{Research context}

The study setting was Wudaoliang village, which is located in Laowa township, Luanping county, Chengde city, Hebei province. The village's per capita annual net income is less than US\$661. Access to the area can be difficult, because it is located in the Yanshan mountain range, with poor transportation links. Local residents have long faced difficulties associated with insufficient drinking water, high living costs and a poor quality of life. Nevertheless, the local government has sought to develop tourism in the village due to its unique topography and the presence of high-quality tourism resources such as the Great Wall and dinosaur egg fossils. In April 2016, the Luanping county government signed a cooperation agreement with Tianxing Jiuzhou Investment Co., Ltd (hereafter TXJZ), which decided to expropriate 110 acres of land in Wudaoliang village. According to Molotch (1976), developing land is the central political goal and raison d'être for local governments. In Wudaoliang's case, this is certainly true: with the development of tourism, land expropriation conflicts have become predominant at the level of both the local government and the local community.

The process of land expropriation for tourism development in Wudaoliang involved three main stakeholders: the local governments, a tourism developer and local residents. From the beginning of the cooperation negotiations, three levels of local government Luanping county, Laowa township and Sandaogou village - interacted with TXJZ and local residents. In China, governments at different levels assume different functions (Zuo et al., 2017). County-level governments are mainly responsible for strategic planning, attracting investment, rule-making and leadership coordination. Township governments are mainly responsible for implementing planning policies, as well as organising land expropriation and house relocation, selecting sites for relocation and other work. Village-level governments are mainly responsible for coordinating and negotiating with residents. Under China's Organic 
Law of Village Committees, villagers' committees are considered not local government organisations, but rather grassroots democratic and self-governance organs. The relationship between a villagers' committee and the township government is not that of an administrative superior and subordinate, i.e., leader and led; rather, it resembles the relationship between a guide and the guided. Villagers' committees play a certain role in tourism development and the distribution of benefits. Although the members of villagers' committees are local residents, however, they are different from ordinary residents, with whom their interests are often not consistent (Wang \& Yotsumoto, 2019). In reality, village committees are often influenced by local governments and responsible for enforcing their will (Wang \& Yotsumoto, 2019). Sandaogou's village committee is no exception. Therefore, in this study, the village committee is called the 'village government'.

\section{Research methods}

Compared with quantitative approaches, qualitative approaches are better suited to assessing the interactions between stakeholders in tourism development (Lee \& Jan, 2019). The authors conducted field research in Wudaoliang for 88 days. Unstructured in-depth interviews and non-participant observation were carried out to obtain relevant behavioural and intentional information on each stakeholder in land expropriation for tourism development in Wudaoliang. Non-participant observation refers to the hidden observation made by researchers when they go deep into the living background of the research object without revealing the real identity of the researcher and participate in the daily social life of the research object, and the significant difference between it and participant observation lies in the difference of immersion (Babbic, 1992). Although we conducted field research for 88 days in the local area, we were only observers of the land expropriation event and not the interest subject of this event. Therefore, we use "non-participant observation" to make the statement, which also used in other tourism literatures (Andriotis, 2010; Chan et al., 2016). Specifically, non-participant observation was used to identify the key events that change the relationships between stakeholders. Unstructured in-depth interviews were used to obtain detailed information on the intentions of the various stakeholders and the relationships between them. In addition, the authors collected statistics and statements on the social and economic development of Wudaoliang, relevant government documents, meeting minutes and information from other secondary sources. The secondary data provided a solid foundation for the presentation of the whole process of land expropriation for rural tourism, and complemented the primary data on the occurrence and development of it. Wudaoliang is the hometown of the first author. This made it easier for the research team to approach the various stakeholders.

Due to China's strong kinship tradition, family is the basic unit of Chinese village society (Fei, 1999). Hence, based on family relationships, the residents of Wudaoliang formed numerous small groups to interact with the government and developer. Therefore, purposive sampling was adopted to find the most representative stakeholders in the process of land expropriation and explore the process and internal mechanisms of their interaction. The non-participant observation identified 76 families who had formed 34 groups. To obtain comprehensive and relevant information, the leaders of each group were selected for in-depth interviews, resulting in a sample of 39: 3 township government workers, 34 individuals categorised as 'residents' ( 25 ordinary residents of the village, 7 residents who worked in other cities and 2 non-residents who lived in other cities but owned real estate in the village) and 2 village cadres ( 1 village party secretary and 1 village director). The content of the in-depth interview focuses on the relationships of three stakeholders while adhering to the social action theory. The relevant questions based on the perspective of actors (three stakeholders), objectives and their specific actions, such as "What do you think about the 
actions of local governments/residents/developers throughout the land expropriation for tourism development?" "What actions have led you to change your view of land expropriation, and what actions have you taken to adapt to the changing situation? Why do you take these actions, the purpose behind them or what is the meaning to you?" It's worth noting that, these questions are not fixed but will be adjusted at any time according to the perspectives of different stakeholders and what they tell, and further in-depth interview questions will be generated according to their content. The average interview time was 36 minutes. The age of the respondents ranged from 17 to 76 . The interviews were conducted in the interviewees' mother language Mandarin. All interviews were recorded, transcribed and then translated into English by two tourism scholars who were professional in both Mandarin and English. After interviews with key figures, the content of the information obtained gradually began to repeat, and eventually no new information appeared. The data analysis indicated that the information provided by the various stakeholders became stable at the $28^{\text {th }}$ informant, and the data provided by the last 11 respondents did not lead to any substantive changes to the codebook. Finally, 180 interviews were conducted, and 536 pieces of original information were collected from the 39 interviewees. To further ensure the trustworthiness of the study, we used the principles suggested by Lincoln and Guba (1985) to assess the credibility of the study. The three authors regularly discussed and cross-verified the analysis results to ensure the reliability and validity of the results to ensure the accuracy and credibility of the results. In terms of peer debriefing, four faculty members at the leading authors' University with research expertise in behavioural psychology and socio-cultural studies were asked to act as disinterested peers and debate with the research team on the design of the interview protocol and the construction of the codebook to improve the credibility and effectiveness of our qualitative study. The raw data were subjected to thematic analysis, which is a systematic technique of identifying, analysing and interpreting patterns in data and classifying the data into 'themes' (Clarke \& Braun, 2017). The analysis consisted of six stages: becoming familiar with the data, generating initial codes, searching for themes, reviewing the themes obtained, defining and naming the themes, and interpreting the meanings of the themes (Creswell, 2014). The quotations used in the findings were each supplemented by details of the participant's number, gender and age and the specific time (year and month) of the interview.

\section{Findings}

The non-participant observation revealed that two key events in the land expropriation process functioned as turning points. The first key event was outlined in two important announcements by the Luanping County People's Government on 16 May 2016: 'Announcement on the Land Planning of Wudaoliang Land in Sandaogou Village' and 'Announcement on the Land Expropriation of Wudaoliang in Sandaogou Village'. These announcements indicated that an agreement had been reached between the government and the developer. The second key event was outlined in the village committee's announcement on 26 July 2017: 'As approved by the township, the land expropriation agreement for residents will be signed between 8:30 a.m. on 26 July 2017 and 4:00 p.m. on 2 August 2017'. The signing of the agreement suggested that upon receiving their compensation, residents would completely lose their right to use the land. Based on these two key events, the land expropriation process can be divided into three stages: 1) before the announcement; 2) after the announcement and before the signing of the agreement; and 3) after the signing of the agreement.

\subsection{Before the announcement}


TXJZ was not the first company to express interest in developing tourism in Wudaoliang. With the increasing popularity of the local area and the success of nearby tourism projects, many investment companies began to pay attention to the tourism development value of Wudaoliang. First, senior management personnel from various enterprises conducted on-the-spot investigations of the area to determine its potential for tourism. To obtain the development and management rights for high-quality investment projects, TXJZ took two main actions. First, the company made several rounds of visits to Wudaoliang to assess the technical feasibility of tourism development and contacted and negotiated with the county government. TXJZ also invited key personnel at the three levels of government to visit project sites that had been built in the early stages of the enterprise's tourism development business. By showcasing its past projects, the company demonstrated to the local government its willingness and ability to develop tourism in Wudaoliang. The purpose of these measures was to create a favourable business atmosphere and secure external support from the local government in the future.

That time it was a Hong Kong company, the tall man was the county party secretary, he had to accompany the inspection. It seems that the county was really attached to the project, we believed they really planned to implement tourism development here. (Participant 36, female, 47, 201604)

The county government is the highest level of local government responsible for decision-making on matters in Wudaoliang. Promoting the economic growth of the village and even the county is not only the core goal of the county government, but also an important component of its performance evaluation. In the context of China's existing tax distribution system, land transfer has become an important channel for local governments to alleviate the pressure of fiscal shortfalls (Zhao \& Yang, 2015). Driven by these goals, the core work of local governments is to actively negotiate with relevant developers and select the strongest and most appropriate. In addition, the government promises to provide preferential policies for developers as far as possible. Compared with the county government, the township and village governments participated much less in the preliminary investigation of tourism development in Wudaoliang. Instead, these two levels of local government were primarily responsible for cooperating with the county government on its tourism development inspection mission.

We have had so much land expropriated by the government. The price paid to the residents is US\$11,765 per acre, then a higher price is paid by the developer. The county can make tens of millions of dollars in a short time. That's why our county has been selling land in recent years. (Participant 4, female, 51, 201603)

The township government does not have the right to decide. It just accompanies [the developer and county government] and provides guidance. (Participant 10, female, 44, 201603)

The residents of Wudaoliang face difficult living conditions. When they were offered compensation for the expropriation of local land, they were convinced that tourism development would improve their quality of life. Before any real investment capital had entered the region, Wudaoliang's residents were generally keen to attract investors, and they came together every day to exchange news on this possibility. A few far-sighted residents implemented a strategic plan. While waiting for capital from investors, they planted saplings on their land to ensure that they would receive higher financial compensation (because different types of crop receive different levels of compensation under China's property and land management laws). However, local residents were not able to participate in the early decision-making process (Table 1).

[We hoped to] develop our village as soon as possible, so that we old couples could get the promised compensation, allowing us to live with our children in Beijing to reduce their 
financial burden. (Participant 5, female, 67, 201601)

We [residents] are like big idiots. The government won't tell you anything until it's time to sign. (Participant 35, male, 41, 201603).

On 11 April 2016, after several rounds of investigation and negotiation, the Luanping county government and TXJZ signed the agreement.

Table 1 Actors, goals, actions and typical events before the announcement

\begin{tabular}{|c|c|c|c|}
\hline Actor & Goals & Actions & Typical events \\
\hline $\begin{array}{l}\text { Tourism } \\
\text { developer }\end{array}$ & $\begin{array}{l}\text { Identify high-quality investors } \\
\text { Create a supportive business } \\
\text { environment } \\
\text { Secure high financial returns }\end{array}$ & $\begin{array}{l}\text { Field visit } \\
\text { Negotiations }\end{array}$ & $\begin{array}{l}\text { Visiting the project site } \\
\text { Inviting the government to } \\
\text { inspect existing projects } \\
\text { Negotiating with the local } \\
\text { government }\end{array}$ \\
\hline $\begin{array}{l}\text { Local } \\
\text { government } \\
\text { (county } \\
\text { government) }\end{array}$ & $\begin{array}{l}\text { Find high-quality tourism } \\
\text { developers to invest } \\
\text { Promote local economic } \\
\text { development or gain political } \\
\text { achievements }\end{array}$ & $\begin{array}{l}\text { Creating } \\
\text { conditions to } \\
\text { attract } \\
\text { investment }\end{array}$ & $\begin{array}{l}\text { Formulating preferential policies } \\
\text { for tourism investment } \\
\text { Inspecting projects built by } \\
\text { tourism developers in advance }\end{array}$ \\
\hline Residents & $\begin{array}{l}\text { Support and cooperate with } \\
\text { local tourism development } \\
\text { Obtain employment or the } \\
\text { return of tourism development } \\
\text { to improve their life }\end{array}$ & $\begin{array}{l}\text { Obtaining } \\
\text { information } \\
\text { Preparing for } \\
\text { development }\end{array}$ & $\begin{array}{l}\text { Gathering for discussion } \\
\text { Planting cash crops with high } \\
\text { compensatory value in advance }\end{array}$ \\
\hline
\end{tabular}

\subsection{After the announcement and before the signing of the agreement}

The reform of China's tax distribution system rapidly reduced local governments' share of government revenue. Insufficient local financial funds have become a key bottleneck restricting local economic development (Zhao \& Yang, 2015). However, local governments have largely retained their power. Due to the decentralisation reform, local governments can be considered relatively independent subjects of interest (Zhang, 2002). Under the reformed tax distribution system, all of the revenue from land transfer is assigned to local governments, enabling local governments to increase their revenue. Luanping county government lacked the fiscal strength required to achieve land expropriation in Wudaoliang through the usual auction procedures. According to China's land management law, land developers must be selected via a bidding, listing and delisting process. Normally, development cannot begin until required legal procedures have been undertaken and residents have been made aware of the plans. However, to obtain the land development rights as quickly and cheaply as possible, after signing the cooperation agreement, TXJZ paid US\$2.94 million in advance to Luanping county government to facilitate the expropriation of 110 acres of land without going through the normal procedures. This advance payment not only relieved the local government's financial pressure, but also expedited the construction process. To communicate and negotiate with local residents as effectively as possible, TXJZ also hired some local influential social elites to deal with daily affairs.

In recent years the government has seen too many dodgy developers. These developers did not send money, they did not dare to [pay for] land expropriation. If they had to spend a lot of money, developers would not buy our land, and the government would suffer huge losses. But our county is poor. This money [the land compensation] was TXJZ's advance payment to the county government. (Participant 4, female, 45, 201701)

When the land expropriation funds were in place, the Luanping county government released two announcements to publicise and explained the work procedures, compensation standards, incentive policies and prohibited behaviours. This demonstrated a remarkable efficiency, as the announcements not only expressed firm support for the developers, but also 
provided a strong foundation for and guarantee of the smooth promotion of land expropriation. Subsequently, under the leadership of the county government, a working group formed by the township and village governments began to sign land expropriation agreements with residents. In particular, village governments and rural elites employed by TXJZ began to play a key role at this stage. Exerting both political power and social influence, they persuaded many residents to accept the land expropriation agreement.

Hurry up and sign the expropriation agreement. Those who sign early get [compensation] early. Early signing will be rewarded. The township signed a written pledge to fulfil a military order, using all means to ensure that the signing proceeded smoothly. (Participant 19, Female, 51, 201609)

After the announcements, further information on the land expropriation was disclosed. For example, the residents were informed that the scope of land expropriation would be limited to 110 acres, with standard compensation of only US\$11,765 per acre. However, land in Wudaoliang was divided into core land and peripheral land. The developer planned to expropriate only 110 acres of prime core land. Whereas the residents had previously been unanimous in their enthusiasm for the project, their attitudes towards and degree of support for tourism development now began to diverge. Some residents planted economically valuable saplings on their land on the night of the announcements. Some residents refused to move their family tombs out of Wudaoliang for emotional reasons. Some hoped to gain favour with the land evaluators. The intrinsic motivation of these actions was to maximise their possible economic benefits. However, as the fundamental goal as expressed at that stage was to improve quality of life, there was no real opposition to tourism development; for example, no opposition groups were formed. Maximising their individual interests by enhancing their relationship with the developer was the main behavioural characteristic of local residents at this stage (Table 2).

What standard did the government use to decide on compensation for the land expropriated? Why did we [residents] receive so little compensation? As the compensation was too low, I was not willing to agree. (Participant 16, male, 42, 201612)

During the 7 working days from 26 July to 2 August 2017, 76 of the 77 households in Wudaoliang village completed the signing of the land expropriation agreement.

Table 2 Actors, goals, actions and events after the announcement and before the signing of the agreement

\begin{tabular}{|c|c|c|c|}
\hline Actor & Goals & Actions & Typical events \\
\hline $\begin{array}{l}\text { Tourism } \\
\text { developer }\end{array}$ & $\begin{array}{l}\text { Acquire the formal land } \\
\text { development right with the } \\
\text { minimum cost and the fastest } \\
\text { speed } \\
\text { Promote project construction }\end{array}$ & $\begin{array}{l}\text { Obtaining extra } \\
\text { support from the } \\
\text { government through } \\
\text { good relationships }\end{array}$ & $\begin{array}{l}\text { Pre-payment for expropriation } \\
\text { of land } \\
\text { Employment of local elites to } \\
\text { address the interests of local } \\
\text { residents }\end{array}$ \\
\hline $\begin{array}{l}\text { Local } \\
\text { governments } \\
\text { (county-township } \\
\text {-village) }\end{array}$ & $\begin{array}{l}\text { Realise land expropriation as } \\
\text { soon as possible } \\
\text { Promote the implementation } \\
\text { of the project } \\
\text { Eliminate 'interference' from } \\
\text { residents s much as possible }\end{array}$ & $\begin{array}{l}\text { Giving extra support } \\
\text { to the developer } \\
\text { through both public } \\
\text { power and private } \\
\text { (personal) } \\
\text { relationships }\end{array}$ & $\begin{array}{l}\text { Formulating land } \\
\text { compensation standards, } \\
\text { incentive schemes, and details } \\
\text { of prohibited behaviours } \\
\text { Persuading residents to sign } \\
\text { through family relationships }\end{array}$ \\
\hline Residents & $\begin{array}{l}\text { Maximise compensation } \\
\text { received for expropriated land } \\
\text { Maximise short-term } \\
\text { individual benefits }\end{array}$ & $\begin{array}{l}\text { Creating obstacles } \\
\text { Obtaining } \\
\text { illegitimate interests } \\
\text { through guanxi }\end{array}$ & $\begin{array}{l}\text { Rapidly planting saplings and } \\
\text { refusing to move tombs to } \\
\text { obtain higher compensation } \\
\text { Building relationships with } \\
\text { land valuers }\end{array}$ \\
\hline
\end{tabular}

6.3. After the signing of the agreement 
To increase the efficiency of project operation and management in the third stage, the developer and Luanping county government established a plan for the overall demolition of buildings and relocating 76 local households as soon as the cooperation agreement had been signed. Unlike other destination tourism development procedures, the land expropriation and house demolition work undertaken for tourism development in Wudaoliang was divided into two steps. Once the basic land expropriation work had been completed, especially the disclosure of plans to resettle households elsewhere, resistance to the development process began to increase. The government-led demolition of residential buildings progressed slowly. The investing companies continued to use local social elites to smooth their interaction with residents, but they also began to release information that could directly or indirectly exert pressure on the local government. They informed the government of the opportunity costs that divestment might bring to the local economy and tried to persuade residents to cooperate with the government in accepting the relocation scheme. Individual residents who steadfastly refused resettlement schemes were attacked in their own homes by unidentified persons. However, these flagrant violations of civilised behaviour and China's modern legal system went unpunished. Unsurprisingly, this placed great psychological pressure on residents, reducing their resistance to the demolition of houses.

The government officials and [representatives of the] developer are really wicked. They made BZW drink drive on purpose and took him to the police station. BYF hit a man with his car a few years ago and they planned to arrest him as well. None of our family members has done anything against the law. We clearly understand that this way of compensation is definitely not good. If it does not change, I will petition against it. (Participant 25, female, 55, 201712)

If negative publicity about house demolition eventually leads developers to withdraw, local governments will face huge default costs. In Wudaoliang, the local government first used both control and compromise to encourage residents to accept the resettlement clause and sign the house demolition agreement. The local government began to use its public power to arrest people who had violated the law or other regulations, especially those who refused to accept the resettlement programme. After arresting the residents, the government offered them resettlement in exchange for exemption from punishment. At the same time, the local government urged civil servants, teachers and other public sector workers to persuade their relatives and friends through warnings and 'exhortations'. They also made residents various promises and set different compensation standards in an attempt to meet their specific needs. These measures undoubtedly became the key external factors promoting residents' acceptance of the relocation plan.

It turned out that BCB was just as adamant as we were about not signing the agreement. Even through they wanted to take him to the police station, he would not compromise. He and his daughter-in-law were both teachers. They were told that if they did not sign, they would be transferred to teach in the most remote valley area in Luanping. All of a sudden, the agreement was signed. You have no place to air your grievances, and your job is in someone else's hands. (Participant 38, male, 45, 201805)

At this stage, with the disclosure of more information on the project, such as plans to relocate residents and provide zero compensation for peripheral land, Wudaoliang's residents increasingly realised that they would be excluded from the tourism development process. They realised that they would not truly share in the dividends of future tourism development. As a result, their sense of ownership and awareness of their right to participate in decision-making on development began to increase. The village's residents began to establish limited coalitions in opposition to the planned demolition and resettlement. They used formal legal means, such as petitions, to advocate for involvement in tourism development decision-making and processes. However, the dominant motivation for these rural residents 
was to improve their livelihoods and gain access to resources, based on the principles of the pursuit of safety and risk avoidance. The pursuit of profit was a secondary motivation, after the fulfilment of security-related needs (Scott, 1976). However, due to various threats from the local government, more and more residents withdrew from the coalitions they had formed. These residents finally decided to accept the terms of the resettlement programme (Table 3 ).

The government's decision-making on the location of the resettlement housing was not transparent and we were not involved at all! (Participant 22, male, 50, 201803)

Our resettlement housing was not in Wudaolaing, but somewhere else. The government and developers were clearly bullying us; if our house was to be built somewhere else, I was not willing to go! (Participant 31, male, 56, 201803)

Of the 77 households in Wudaoliang, 76 accepted the relocation plan, but the local government and developer did not have enough patience to wait until the last household had agreed. On 1 May 2018, tourism development in Wudaoliang officially broke ground, and the roar of large machines began to echo through the small mountain village.

Table 3 Actors, goals, actions and events after the signing of the agreement

\begin{tabular}{|c|c|c|c|}
\hline Actor & Goals & Actions & Typical events \\
\hline $\begin{array}{l}\text { Tourism } \\
\text { developer }\end{array}$ & $\begin{array}{l}\text { Complete the demolition as } \\
\text { soon as possible } \\
\text { Promote project construction } \\
\text { and settle local residents in } \\
\text { other places }\end{array}$ & $\begin{array}{l}\text { Putting pressure on } \\
\text { the government } \\
\text { Putting pressure on } \\
\text { residents }\end{array}$ & $\begin{array}{l}\text { Constantly releasing } \\
\text { divestment information } \\
\text { Local residents attacked in } \\
\text { their homes by } \\
\text { unidentified people }\end{array}$ \\
\hline $\begin{array}{l}\text { Local } \\
\text { government } \\
\text { (county-township } \\
\text {-village) }\end{array}$ & $\begin{array}{l}\text { Complete the house } \\
\text { demolition agreement as } \\
\text { soon as possible } \\
\text { Reassure the local population } \\
\text { Implement the project } \\
\text { smoothly }\end{array}$ & $\begin{array}{l}\text { Abusing power } \\
\text { Pursuing illegitimate } \\
\text { interests }\end{array}$ & $\begin{array}{l}\text { Arrest of residents or their } \\
\text { close relatives who had } \\
\text { violated laws and } \\
\text { regulations } \\
\text { Sowing division between } \\
\text { residents through the } \\
\text { influence of relatives and } \\
\text { friends }\end{array}$ \\
\hline Residents & $\begin{array}{l}\text { Participate in the Wudaoliang } \\
\text { tourism development process } \\
\text { Obtain higher compensation } \\
\text { for subsequent house } \\
\text { demolition }\end{array}$ & $\begin{array}{l}\text { Building self- } \\
\text { organised coalitions } \\
\text { with the help of } \\
\text { exogenous forces }\end{array}$ & $\begin{array}{l}\text { Forming interest } \\
\text { organisations against the } \\
\text { demolition and relocation } \\
\text { Forming groups to petition } \\
\text { provinces and cities }\end{array}$ \\
\hline
\end{tabular}

\section{Wudaoliang as a tourism growth machine}

Game-playing processes similar to those associated with urban growth occur in relation to land and stakeholders in the process of rural tourism development in China. In terms of land expropriation and housing demolition, which are major wealth-related issues, the game structure covers the interests of local governments at the county, township and village levels, tourism developers and local residents. However, the local political structure formed in the process of rural tourism development in China is unbalanced, due to rural residents' lack of social autonomy and capacity for political participation (Ying \& Zhou, 2007). Local residents are in a very weak position - even in land expropriation and housing demolition affairs that involve their own major interests (Wang \& Yotsumoto, 2019). Few residents are able to engage in effective discourse with the government and developers. In contrast, the government's administrative power makes it both an interest participant and a source of political rights in rural economic and social development, as the government has the authority to make rules for tourism development. Further, to increase their fiscal revenue, improve their political performance and foster local economic growth, local governments are often willing to combine their administrative power with the huge capital of developers. Developers also 
hope to obtain greater returns on project investment, and thus cooperate with local governments with rich political resources to secure a more cooperative external environment in the search for profits. Therefore, considering the interactive game structure of individual subjects of interest in the tourism development growth machine and taking account of Chinese characteristics, a 'rural tourism development growth machine' composed of 'political elites' and 'economic elites' is formed, which is consistent with the early growth of cities. The whole process of rural tourism development is government-led, with the growth coalition as its core (Fig. 1).

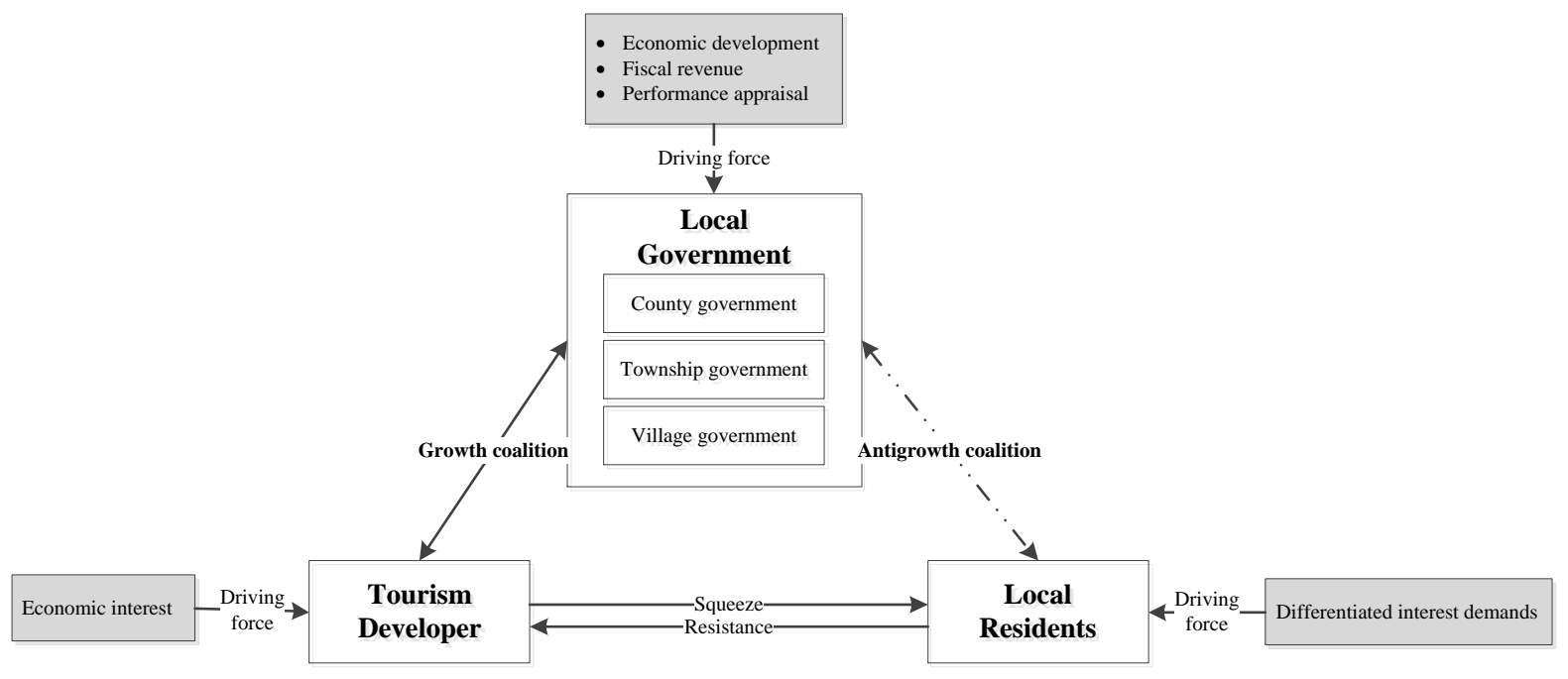

Fig. 1. Triadic relationship between stakeholders during the process of land expropriation Notes: The solid line indicates the establishment of a coalition relationship between actors.

The dotted line represents a failed attempt to establish the coalition relationship between actors.

Before the announcements, Wudaoliang's residents responded positively to the simple appeal to participate in tourism development and thereby improve their living conditions. Their demands were in line with the goal of the local government and developer, namely to promote the implementation of the tourism projects to obtain mutual benefits. As a result, the three parties initially supported and cooperated with each other. The interests of the three parties in rural tourism development formed a relatively loose structure and a growth coalition in the short period before the expropriation of funds was actually implemented. With the release of the abovementioned twin announcements, more relevant information was disclosed. At this point, local residents became aware that some benefits were not reasonably guaranteed. They began to deliberately create obstacles to maximise their individual interests through the implementation of the project, and their goals began to diverge from those of the government and developer. The local government and developer continued to cooperate in guarding against the risk of loss caused by project failure. The two sides eventually formed a more solid growth coalition that essentially excluded residents. That is to say, the core role of the local government after the release of the two announcements was to promote the implementation of development without the interference of local residents. The status of the government shifted from that of an intermediary or bridge (before the release of the announcements) to that of a service provider for the tourism developer (after the announcements).

The signing of the agreement indicated that residents' initial demand to participate in the tourism development process and improve their living conditions had been completely overturned. At this stage, the interests and goals of residents ran completely counter to those 
of the local government and developer. Some residents began to fight for their interests against the local government and developer through procedural justice and legal means. Through this struggle, the interests of the local government, the developer and residents each became more prominent. Ultimately, this conflict promoted a more stable growth coalition between the local government and developer. Generally, in the process of land expropriation for rural tourism development in China, based on common economic interests and value expectations, local governments and developers gradually form a more and more stable growth coalition. Research has shown that when such a growth coalition harms the interests of other interest groups, the victimised groups will often form an anti-growth coalition (Zhang, 2002), impeding the implementation of the action programme of the growth coalition (Molotch, 1976). However, due to differentiated value demands, such as local residents' economic and emotional interests, as well as differences in the willingness to participate in and enthusiasm for tourism development, the anti-growth coalition often observed in urban research did not form in the process of rural tourism development in Wudaoliang. In reality, given the residents' weak position, the local government and developer had far more opportunities to intervene in and sabotage the organisational structures formed by rural residents. This was due to both subjective constraints and objective factors. The subjective constraints included the diverse interests and demands of individual rural residents (Byrd, 2007) and their limited ability to participate. The objective factors included the administrative and economic support for the alliance centred on the local government. Foreign capital is the key driving force for the transformation of China's traditional rural social structure. Under this influence, each subject takes its own interests as its guide for action, producing complexly interwoven and interactive relationships between subjects. Foreign capital depends on power to play its role.

\section{Implications}

This study offers new insights into the logic and mechanisms of the interaction and relationships between stakeholders in the process of land expropriation for rural tourism development. The results of this study can be used to evaluate the criteria determining each stakeholder's actions, and provide a useful reference for solving conflict and promoting cooperation between stakeholders in sustainable tourism development in the future.

\subsection{Theoretical implications}

This study provides rich theoretical insights by exploring the logic and underlying mechanisms of stakeholders' relationships, interactions and actions in the land expropriation stage of rural tourism development. First, its findings enrich research on the roles of tourism stakeholders in sustainable rural tourism development, especially in terms of social sustainability. Sustainable tourism has become a mainstream issue of concern among both tourism scholars and tourism practitioners, calling for embedded analysis of different stakeholders (Waligo et al., 2015). However, previous studies have focused on identifying stakeholders and calling for cooperation between them, ignoring the interaction and relationships between stakeholders in tourism development (Wearing et al., 2010). Yet clarifying the specific logic of stakeholders' interaction and actions and seeking common interests are crucial to promote cooperation between stakeholders and guide the sustainable development of rural tourism (Lee \& Jan, 2019). Different stakeholders in tourism development have different interests (Donaldson \& Preston, 1995). Diverging from previous literature, this study describes and evaluates the complicated relationships between different stakeholders. The findings of this study contribute to the literature on cooperation between stakeholders in the sustainable development of rural tourism. 
Second, this study offers a pioneering adaptation of the sociologist Max Weber's theoretical explanation of social action from the general social psychology field to studies of residents' involvement in tourism. It develops an 'actor-goal-action-typical events' framework for analysis of the relationships between different stakeholders in rural tourism development. With the help of this analytical framework, the process of interaction between different stakeholders is fully deconstructed. The innovative introduction of sociological theory to explain the phenomenon of tourism development opens up a new path for future research.

Third, this study adapts growth machine theory to explain the logic and internal mechanisms of stakeholders' interaction in land expropriation for rural tourism development. Most studies to date have applied growth machine theory to urban economic development. However, growth machine theory offers a useful theoretical context to help tourism researchers explain local economic growth and development with reference to political coalitions and land use allocation (Canan \& Hennessy, 1989; Harrill et al., 2011). Through the theory of growth alliances, the vulnerability of tourism coalitions is revealed and the dynamic and complex relationships between different stakeholders are presented. The essential insights provided by this study thus serve as a cornerstone for future tourism coalition research.

\subsection{Practical implications}

The findings of this study have not only theoretical implications, but also implications for governments at different levels and the developers of tourism destinations. The study provides guidance and a useful point of reference for sustainable tourism development in developing countries.

In the land expropriation stage of rural tourism, introducing a third-party stimulus to cultivate the development of an anti-growth alliance and ensure residents' full participation in the tourism development process is fundamental to realising the rights of local people and negotiating an appropriate price with the growth coalition. The findings reveal the disadvantaged position of local residents in tourism development, especially in developing countries. It is widely accepted that sustainable tourism development requires residents to be involved in the planning process and to actively support the tourism sector (Nunkoo \& Ramkissoon, 2012). However, local community groups often have limited access to outside resources, limiting their contribution to tourism development and, consequently, their ability to take advantage of the benefits of tourism development (Nunkoo, 2017; Sautter \& Leisen, 1999). Although governments and elite stakeholders have a direct and powerful influence on tourism development discourse, public interests tend to be marginalised (Dredge, 2010). However, residents should be at the centre of destinations' tourism development (Nunkoo, 2017). Therefore, local governments should consider enhancing community participation (Wang et al., 2010), reducing social conflict and promoting the sustainable development of local tourism.

Local governments and developers should pay more attention to the value demands of residents to reduce social conflicts and promote the sustainable development of rural tourism. This study shows that tourism development in many rural areas is a power game. There is an imbalance of power between interest subjects. Local governments are the dominant players in this power game (Wang \& Wall, 2007). Due to their authority and economic strength, they tend to come out on top in conflicts with local residents (Wang \& Yotsumoto, 2019; Yang \& Zhou, 2007). Local governments and tourism developers form the primary partnership in the rural tourism development process due to the power and resources they hold (Li et al., 2016). The imbalance of power leads to conflict among stakeholders in tourism development. Balancing the power and interests of different stakeholders is vital to enhance the dialogue 
and cooperation between interest subjects for sustainable tourism (Jamal \& Getz, 1995). Therefore, the government should play a proper role in the process of tourism development. Local governments form a 'growth coalition' with tourism developers, which focus on achieving economic interests. They must facilitate bottom-up approaches to decision-making (Madrigal, 1995). Strengthening residents' participation in tourism development, formulating reasonable rules and systems for tourism development and demolition, and resisting the formation of unreasonable growth coalitions have become important tasks for the smooth expropriation of land for tourism development, which is vital to the stable and sustainable development of rural tourism in the future.

\section{Conclusion and limitations}

Exploring the processes and internal mechanisms of the interaction between different stakeholders in rural tourism is a prerequisite for promoting cooperation between stakeholders on future sustainable tourism development. Through non-participant observation and 180 interviews with 39 respondents, this study delineates these processes and mechanisms in the land expropriation for rural tourism development in China.

Using a novel 'actor-goal-action-typical events' analysis framework, this study is the first to adapt social action theory to deconstruct the process of interaction between different stakeholders in land expropriation for rural tourism development in China. In the context of land expropriation for tourism development in rural China, stakeholders' relationships are not merely cooperative or antagonistic; they show a pattern of phased evolution of interwoven interests with the occurrence and development of key events. This study also uses growth machine theory to reveal the logic and internal mechanisms of the actions and interaction of different stakeholders. In contrast with previous studies, this study applies growth machine theory in the context of rural tourism, which is different from (and much more precarious than) general urban tourism. At the core of the framework is the formation of a growth coalition between political elites, as represented by the government, and economic elites, represented by the developer. However, local residents in the case setting, Wudaoliang, failed to form an anti-growth coalition in the process of rural tourism development.

This study's findings offer guidance for the Chinese government and developers on pursuing sustainable rural tourism development. To promote social stability, they should pay more attention to the interests of residents, who are in a comparatively weak position.

However, this study also has limitations. First, it focuses solely on the context of land expropriation for rural tourism development, which belongs to the pre-tourism development stage. With the continuous development of destination tourism, more stakeholders emerge at different stages, such as tourists. The interaction and relationships between them take more complex forms than examined in this study. In addition, due to the conflict of interests, no developers agreed to be interviewed for this study. As the Chinese government considers its own interests in tourism development and forms a coalition with developers, government officials avoid talking about related issues in interviews. Therefore, most of our interviews were conducted with residents. In future research, information could be acquired from multiple subjects and different tourism development stages could be examined to more fully reveal the interactive game relations of the various subjects of interest.

\section{References}

Andriotis, K. (2010). Heterotopic erotic oases. Annals of Tourism Research, 37(4), 107 6-1096.

Ayhan, Ç. K., Taşlı, T. C., Özkök, F., \& Tatlı, H. (2020). Land use suitability analysi s of rural tourism activities: Yenice, Turkey. Tourism Management, https://doi.org/ 
10.1016/j.tourman.2019.07.003

Babbie, E. R. (1992). The practice of social research. Wadsworth, Cengage learning P ress.

Banton, M. (2007). Max Weber on 'ethnic communities': A critique. Nations and Nationalism, 13(1), 19-35.

Bramwell, B., \& Sharman, A. (1999). Collaboration in local tourism policymaking. Annals of Tourism Research, 26(2), 392-415.

Brunt, P., \& Courtney, P. (1999). Host perceptions of sociocultural impacts. Annals of Tourism Research, 26(3), 493-515.

Byrd, E. T. (2007). Stakeholders in sustainable tourism development and their roles: applying stakeholder theory to sustainable tourism development. Tourism review, 62(2), 6-13.

Cai, M. (2016). Land for welfare in China. Land Use Policy, 55, 1-12.

Canan, P., \& Hennessy, M. (1989). The growth machine, tourism, and the selling of culture. Sociological Perspectives, 32(2), 227-243.

Chan, J. H., Iankova, K., Ying, Z., McDonald, T., \& Qi, X. (2016). The role of selfgentrification in sustainable tourism: indigenous entrepreneurship at Honghe Hani Rice Terraces world heritage site, China. Journal of Sustainable Tourism, 24(7-9), 1262-1279.

Clarke, V., \& Braum, V. (2017). Thematic analysis. The Journal of Positive Psychology, 12(3), 297-298.

Coleman, J. S. (1986). Social theory, social research, and a theory of action. American Journal of Sociology, 91(6), 1309-1335.

Creswell, J.W. (2014). A concise introduction to mixed methods research. Los Angeles: Sage Publications.

Donaldson, T., \& Preston, L. E. (1995). The stakeholder theory of the corporation: Concepts, evidence, and implications. Academy of Management Review, 20(1), 65-91.

Dredge, D. (2010). Place change and tourism development conflict: Evaluating public interest. Tourism Management, 31(1), 104-112.

Fei, X. (1999). Reconstructing rural China. Beijing, Qunyan Press. (In Chinese)

Freeman, R. E. (1984). Strategic management: A stakeholder approach. Boston: Pitman.

Green, G. P., Marcouiller, D., Deller, S., Erkkila, D., \& Sumathi, N. R. (1996). Local dependency, land use attitudes, and economic development: Comparisons between seasonal and permanent residents. Rural Sociology, 61(3), 427-445.

Guo, L., \& Gao, G. (2014). Research on the landless intention of land-lost peasants in poverty-stricken areas based on logistic models: Taking Bijie prefecture of Guizhou province as the object for empirical research. Natural Resource Economics of China, 27(4), 68-72.

Guo, X. L. (2001). Land expropriation and rural conflicts in China. The China Quarterly, 166, 422-439.

Hall, C. M. (1999). Rethinking collaboration and partnership: A public policy perspective. Journal of Sustainable Tourism, 7(3), 274-289.

Hanna, K. S. (2005). Planning for sustainability: Experiences in two contrasting communities. Journal of the American Planning Association, 71(1), 27-40.

Hardy, A. L., \& Beeton, R. J. (2001). Sustainable tourism or maintainable tourism: Managing 
resources for more than average outcomes. Journal of Sustainable Tourism, 9(3), 168-192.

Harrill, R., Uysal, M., Cardon, P., Vong, F., \& Dioko, L. (2011). Resident attitudes towards gaming and tourism development in Macao: Growth machine theory as a context for indentifying supporters and opponents. International Journal of Tourism Research, 13(1), 41-53.

Hernandez, S. A., Cohen, J., \& Garcia, H. L. (1996). Residents' attitudes towards an instant resort enclave. Annals of Tourism Research, 23(4), 755-779.

Jamal, T., \& Getz, D. (1999). Community roundtables for tourism-related conflicts: The dialectics of consensus and process structures. Journal of Sustainable Tourism, 7(3-4), 290-313.

Jamal, T., \& Stronza, A. (2009). Collaboration theory and tourism practice in protected areas: stakeholders, structuring and sustainability. Journal of Sustainable Tourism, 17(2), 169-189.

Kim, K., Uysal, M., \& Sirgy, M. J. (2013). How does tourism in a community impact the quality of life of community residents?. Tourism Management, 36, 527-540.

Lee, T. H., \& Jan, F. H. (2019). Can community-based tourism contribute to sustainable development? Evidence from residents' perceptions of the sustainability. Tourism Management, 70, 368-380.

Li, P., Ryan, C., \& Cave, J. (2016). Chinese rural tourism development: Transition in the case of Qiyunshan, Anhui.-2008-2015. Tourism Management, 55, 240-260.

Lincoln, Y. S., \& Guba, E. G. (1985). Naturalistic inquiry. Beverly Hills, CA: Sage Publications.

Ma, X. L., Dai, M. L., \& Fan, D. X. (2020). Land expropriation in tourism development: Residents' attitudinal change and its influencing mechanism. Tourism Management, https://doi.org/10.1016/j.tourman.2019.103957.

Madrigal, R. (1995). Residents' perceptions and the role of government. Annals of Tourism Research, 22(1), 86-102.

Markwick, M. C. (2000). Golf tourism development, stakeholders, differing discourses and alternative agendas: the case of Malta. Tourism Management, 21(5), 515-524.

Martin, B. S. (1999). The efficacy of growth machine theory in explaining resident perceptions of community tourism development. Tourism Analysis, 4(1), 47-55.

Ministry of Agriculture and Rural Affairs. (2019). Analysis on the development status and prospect of rural tourism market in China. Retrieved from: https://baijiahao.b aidu.com/s?id=1629231733740378530\&wfr=spider\&for $=$ pc.

Molotch, H. (1976). The city as a growth machine: Toward a political economy of place. American Journal of Sociology, 82(2), 309-332.

Molotch, H., \& Logan, J. (1984). Tensions in the growth machine: Overcoming resistance to value-free development. Social Problems, 31(5), 483-499.

Nunkoo, R. (2017). Governance and sustainable tourism: What is the role of trust, power and social capital?. Journal of Destination Marketing \& Management,6(4), 277-285.

Nunkoo, R., \& Ramkissoon, H. (2012). Power, trust, social exchange and community support. Annals of Tourism Research, 39(2), 997-1023.

Panyik, E., Costa, C., \& Rátz, T. (2011). Implementing integrated rural tourism: An 
event-based approach. Tourism Management, 32(6), 1352-1363.

Ploger, J. (2001). Public participation and the art of governance. Environment and Planning B: Planning and Design, 28(2), 219-241.

Purdy, J. M. (2012). A framework for assessing power in collaborative governance processes. Public Administration Review, 72(3), 409-417.

Qian, C., Sasaki, N., Jourdain, D., Kim, S. M., \& Shivakoti, P. G. (2017). Local livelihood under different governances of tourism development in China: A case study of Huangshan mountain area. Tourism Management, 61, 221-233.

Qin, Q., Wall, G., \& Liu, X. (2011). Government roles in stimulating tourism development: A case from Guangxi, China. Asia Pacific Journal of Tourism Research, 16(5), 471-487.

Sanders, H. T., \& Stone, C. N. (1987). Developmental politics reconsidered. Urban Affairs Review, 22(4), 521-539.

Sargeson, S. (2016). Grounds for self-government? Changes in land ownership and democratic participation in Chinese communities. The Journal of Peasant Studies, 45(2), 321-346.

Sautter, E. T., \& Leisen, B. (1999). Managing stakeholders a tourism planning model. Annals of Tourism Research, 26(2), 312-328.

Stoddarta, M. C. J., Catano, G., Ramos, H., Vodden, K., Lowery, B., \& Butters, L. (2019). Collaboration gaps and regional tourism networks in rural coastal communities. Journal of Sustainable tourism, https://doi.org/10.1080/09669582.2019.1694526.

Stone, C. N. (1993). Urban regimes and the capacity to govern: a political economy approach. Journal of Urban Affairs, 15(1), 28.

Su, B. (2011). Rural tourism in China. Tourism Management, 32(6), 1438-1441.

Tosun, C. (2000). Limits to community participation in the tourism development process in developing countries. Tourism management, 21(6), 613-633.

Waligo, V. M., Clarke, J., \& Hawkins, R. (2013). Implementing sustainable tourism: A multi-stakeholder involvement management framework. Tourism management, 36, 342-353.

Waligo, V., Clarke, J., \& Hawkins, R. (2015). Embedding stakeholders in sustainable tourism strategies. Annals of Tourism Research, 55, 90-93.

Wang, L., \& Yotsumoto, Y. (2019). Conflict in tourism development in rural China. Tourism Management, 70, 188-200.

Wang, Y., Wall, G. (2007). Administrative arrangements and displacement compensation in top-down tourism planning: A case from Hainan Province, China. Tourism Management, 28(1), 70-82.

Wearing, S. L., Wearing, M., \& McDonald, M. (2010). Understanding local power and interactional processes in sustainable tourism: Exploring village-tour operator relations on the Kokoda Track, Papua New Guinea. Journal of Sustainable Tourism, 18(1), 61-76.

Weaver, D., \& Oppermann, M. (2000). Tourism management. John Wiley and Sons.

Weber, M. (1949). "Objectivity" in social science and social policy. The Methodology of The Social Sciences, 49-112.

Weber, M. (1978). Economy and society: An outline of interpretive sociology (Vol. 1). Berkeley: Univ of California Press.

Wondirad, A., Tolkach, D., \& King, B. (2020). Stakeholder collaboration as a major factor for sustainable ecotourism development in developing countries. Tourism Management, 
https://doi.org/10.1016/j.tourman.2019.104024.

Wray, M. (2009). Policy communities, networks and issue cycles in tourism destination systems. Journal of Sustainable Tourism, 17(6), 673-690.

Ying, T., \& Zhou, Y. (2007). Community, governments and external capitals in China's rural cultural tourism: A comparative study of two adjacent villages. Tourism Management, 28(1), 96-107.

Zhang, T. W. (2002). Urban development and a socialist pro-growth coalition in Shanghai. Urban Affairs Review, 37(4):475-499.

Zhao, W. Z., Yang, J. D. (2015). Local government finance gap and land transfer mode -based on the explanation of mutually beneficial behaviour between local government and state-owned enterprises. Management World, 30(4):11-24.

Zhou, L., Chan, E., \& Song, H. (2017). Social capital and entrepreneurial mobility in early-stage tourism development: A case from rural China. Tourism Management, 63, 338-350.

Zuo, B., Gursoy, D., \& Wall, G. (2017). Residents' support for red tourism in China: The moderating effect of central government. Annals of Tourism Research, 64, 51-63. 